\title{
Effect of flower regulation on biotic and abiotic stress management in Pomegranate (Punica granatum L.) under hot arid climate
}

\section{R Kumar, SM Haldhar, JS Gora \& MK Berwal}

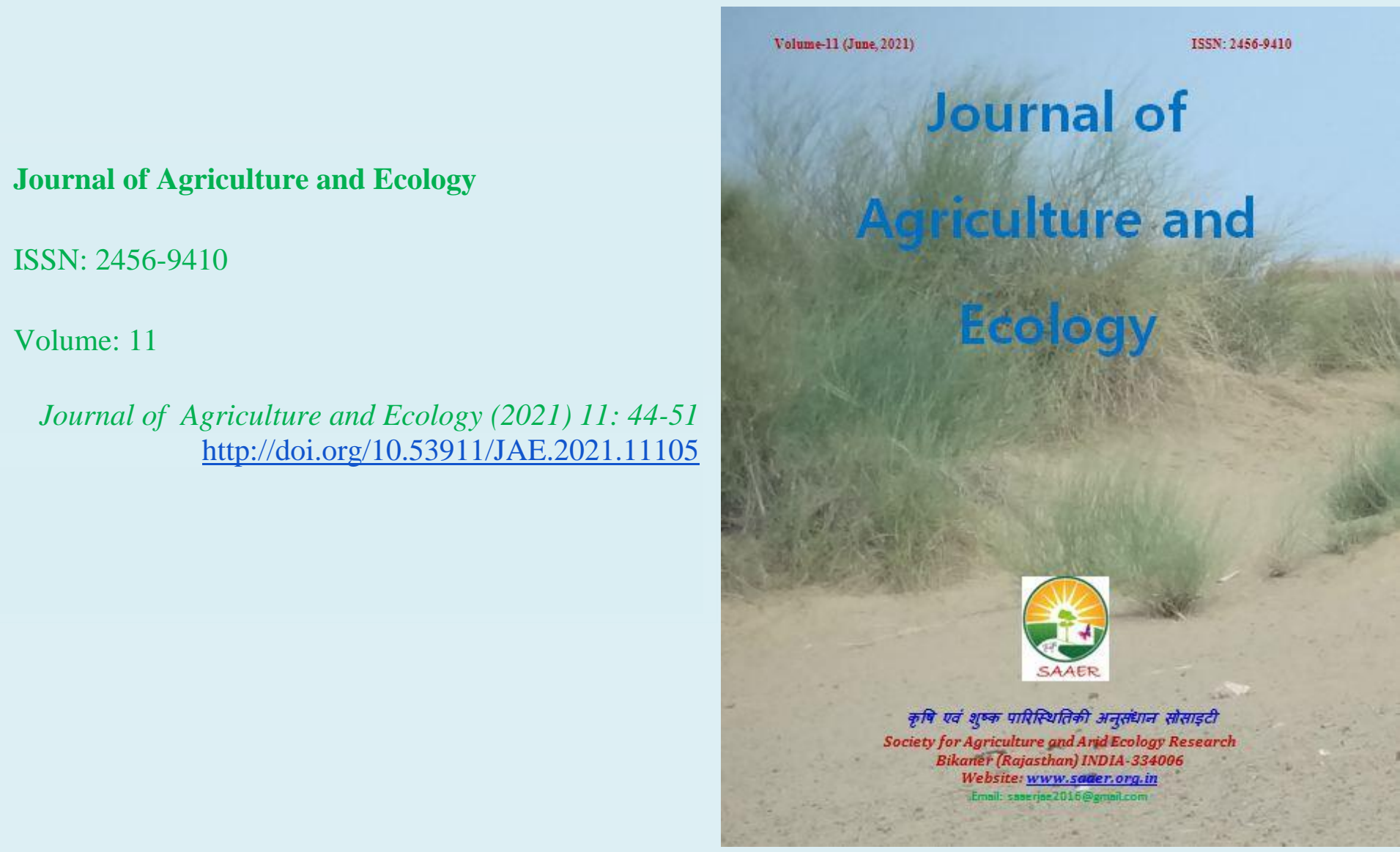




\title{
Effect of flower regulation on biotic and abiotic stress management in Pomegranate (Punica granatum L.) under hot arid climate
}

\author{
R Kumar \, SM Haldhar ${ }^{1}$, JS Gora \& MK Berwal \\ ICAR-Central Institute for Arid Horticulture, Bikaner-334 006, Rajasthan, India \\ ${ }^{1}$ College of Agriculture, Central Agricultural University, Imphal- 795004, India \\ $\not$ Corresponding author: R Kumar,E-mail: rameshflori@gmail.com
}

\section{Article Info}

Article history

Received: 01 May 2021

Accepted: 25 June 2021

Available online: 30 June 2021

Key Words: Flower regulation, mite, fungal spot, fruit cracking.

\begin{abstract}
The present study was carried out for management of abiotic stresses (fruit cracking) and biotic stresses (mite and fungal spot) in pomegranate by flower regulation through water stress, pruning and ethrel application. The results revealed that horticultural interventions, chemical treatments and their interactions significantly minimized mite, fungal spot and fruit cracking incidence in pomegranate. In different combinations treatments of horticultural interventions and chemical, minimum mite incidence (4.80 and $4.65 \%)$ and fungal spot incidence $(9.17$ and $7.83 \%)$ were recorded in withholding irrigation during June + pruning + thinning with ethrel $2 \mathrm{ml} / \mathrm{l}$ treatment as compared to maximum mite (31.95 and $27.51 \%)$ and fungal spot (35.78 and 32.58\%) recorded in control natural flowering without chemicals during the years 2017-18 and 2018-19, respectively. Lower fruit cracking incidence i.e. $<2.0 \mathrm{~kg} / \mathrm{plant}$ was observed in withholding of irrigation during June + pruning + thinning with ethrel applications in both years. The maximum fruit cracking (2.51 and $3.24 \mathrm{~kg} / \mathrm{plant})$ was recorded in withholding of irrigation during March without chemicals treatment during 2017-18 and 2018-19, respectively. Therefore, it can be concluded that withholding irrigation during June + pruning + thinning with ethrel $2 \mathrm{ml} / \mathrm{l}$ treatment reduced mite and fungal spot incidence and fruit cracking through induction of flowering and fruit growth during optimal climatic conditions and enhanced management.
\end{abstract}

Copyright (C2021 Kumar et al., This is an open access article published under the terms of the Creative Commons Attribution License, which permits unrestricted use, distribution, and reproduction in any medium, provided the original work is properly cited.

Preferred citation: R Kumar, SM Haldhar, JS Gora \& MK Berwal. 2021. Effect of flower regulation on biotic and abiotic stress management in Pomegranate (Punica granatum L.) under hot arid climate. Journal of Agriculture and Ecology, 11: 44-51; http://doi.org/10.53911/JAE.2021.11105.

\section{Introduction}

Pomegranate (Punica granatum L.) is an emerging fruit crop of hot arid regions of India. It is grown commercially in the states of Maharashtra, Gujarat, Karnataka, Andhra Pradesh, Telangana, Tamil Nadu, Madhya Pradesh and Rajasthan. India is one of the largest growers and producers of pomegranate in the world. In India pomegranate is grown in 2.62 lakh ha area with 30.34 lakh tonnes annual production and a productivity of 11.58 tonnes/ha (Anonymous 2019). Pomegranate has ability to tolerate abiotic stresses i.e. heat, drought and saline conditions prevailed in hot 
arid regions. The area under pomegranate cultivation in hot arid region is increasing continuously owing to its high demand, hardy nature, better storage quality and nutritional value. It has enormous medicinal, therapeutic values and one of the richest sources of antioxidants. A large number of value added products are developed by processing the fruit such as juices, squash, jelly, wine, seed oil, mouth freshener, etc. In Rajasthan, it is mostly grown in Jaipur, Ajmer, Alwar, Tonk, Sri Ganganagar, Pali, Kota, Jalore, Banswara, Sawai Madhopur, Bhilwara, Jhunjhunu and Sirohi districts over 16,000 ha area. The area under pomegranate cultivation in Thar desert particularly Barmer, Jaisalmer and Jodhpur is increasing at faster rate. Under arid and semiarid regions, about $25-60 \%$ fruit cracking has been reported during maturity in different bahars which varies with variety, season and climate. The cracked fruits are sweeter with low shelf life; highly liable to fruit rot and are unsuitable for transport (Saroj and Kumar 2019). Under hot arid climate, mite and fungal spot are also severe problem in pomegranate cultivation. Mites (Tenuipalpus punicae) remain most active during dry spell from April to October. Shiny white or brown patches can be seen on the undersurface of affected leaves which may further curl and fall. The mite incidence was varied from 6.5 to 63.00 among different cultivars of pomegranate under hot arid climate (Anonymous 2020). During rainy season from July to October, the fungal spot and rot (Colletotrichum gloeosporiodes) causes severe damage in pomegranate under hot arid climate. Fruit spot are hard, minute, dark black to brownish black, irregular shape or size, sometimes spots with light centre and dark brown black edges. Colletotrichum rot causes discolouration of fruits which start from calyx end. The discoloured area becomes dry and reddish brown to black after coalesce of spots The rot extends beyond rind into the arils which disintegrate and are dark grey/brown black colour but not watery (Kumar et al. 2018; Maheshwari \& Haldhar 2018). The mite and fungal spot infestation also increase the incidence of fruit cracking in pomegranate. The frost incidence, low temperature $\left(<5^{\circ} \mathrm{C}\right)$, diurnal temperature variation $\left(>18^{\circ} \mathrm{C}\right)$ and water stress/imbalance are major factors which affects fruit cracking in pomegranate under hot arid climate. Apart from this, improper nutrient management $(\mathrm{Ca}$, $\mathrm{B}$ and $\mathrm{C}: \mathrm{N}$ ratio), water, canopy, pest and disease management without apposite flower regulation contribute significantly in deterioration of overall plant health which determine severity of fruit cracking in pomegranate. In pomegranate fruit development, these factors cause an asymmetric increase in turgor pressure of fruit. The aril turgor increased rapidly than peel turgor pressure due to abnormal growth/drying of peel. This difference in turgor pressure of the arils and peel causes fruit cracking.

Pomegranate flowers continuously under hot arid climatic conditions and produce low yield irregularly at different period of the year, which may not be desirable commercially. To avoid this plants are subjected to flower regulation/bahar treatment. The availability of irrigation water/rainfall, climatic condition, insect-pests, diseases, and market demand are major considerations for flower regulation. Water stresses causes a 
wide array of plant responses, ranging from plant growth, leaf defoliation, flower induction and finally productivity (Kumar et al. 2019a). Moisture stress, plant bioregulators, defoliants, nutrient and canopy management including training, pruning and thinning are major horticultural interventions which influence flowering and fruit quality in pomegranate (Kumar et al. 2019b). In pomegranate, one to two month stress is imposed by the withholding irrigation with light pruning depending upon soil and climatic condition. Withholding of irrigation during June + pruning and thinning + ethrel $2 \mathrm{ml} \mathrm{l-1}$ + DAP 5 g 1-1 treatment induced flowering during optimal climatic conditions and significantly improved sex ratio (bisexual flowers) and fruit set of pomegranate (Kumar et al. 2020). In pomegranate cultivation, fruit cracking is major problem under hot arid climate which deteriorate fruit quality and reduce yield. Therefore, the present study was conducted to induce flowering at the desired period for management of fruit cracking and improvement of quality fruit yield.

\section{Materials and Methods}

The present investigation was carried out during two consecutive years 2017-18 and 2018-19 at ICAR-CIAH, Bikaner. The experiment was conducted in Factorial RBD consisted of 20 treatment combinations replicated thrice. There were two factors i.e. horticulture interventions and chemical applications. The horticulture interventions had five levels i.e. $\mathrm{P}_{0}$-control natural flowering, $\mathrm{P}_{1}$-withholding of irrigation during March, $\mathrm{P}_{2}$-withholding of irrigation during March + pruning and thinning, $\mathrm{P}_{3^{-}}$ withholding of irrigation during June and $\mathrm{P}_{4}$ withholding of irrigation during June + pruning and thinning; while chemical applications have four levels i.e. $\mathrm{C}_{0}$-control without chemicals, $\mathrm{C}_{1}$-ethrel $1 \mathrm{ml} / \mathrm{l}+\mathrm{DAP} 5$ $\mathrm{g} / \mathrm{l}, \mathrm{C}_{2}$-ethrel $2 \mathrm{ml} / \mathrm{l}+\mathrm{DAP} 5 \mathrm{~g} / \mathrm{l}$ and $\mathrm{C}_{3}$-ethrel $3 \mathrm{ml} / 1$ + DAP $5 \mathrm{~g} / \mathrm{l}$. In pruning, $20 \mathrm{~cm}$ of new growth was removed through secateurs after withholding of irrigation period. In thinning, deblossoming was done manually before and during water stress period and only regulated flowers produced after treatment application were allowed to set fruits. The foliar spray of ethrel (40\%) and DAP (18:46 grade) were applied after withholding of irrigation period and pruning, while in control $\left(\mathrm{P}_{0}\right)$ treatments, treatments were applied in last week of May. The Bordeaux mixture $1 \%$ was applied uniformly to all plants after defoliation as a phytosanitary measure. The experiment was conducted on 8 years old plants of pomegranate $\mathrm{cv}$. Jalore Seedless grown at $5 \times 2.5 \mathrm{~m}^{2}$ spacing under drip irrigation. The mean monthly weather data during experimentation are presented in Fig. 1. The soil of pomegranate orchard was loamy sand with $\mathrm{pH}$ of 8.32 and electrical conductivity of $0.27 \mathrm{dSm}^{-1}$. It had $0.15 \%$ organic carbon, $106.4 \mathrm{~kg} / \mathrm{ha}$ available nitrogen, $11.51 \mathrm{~kg} / \mathrm{ha}$ available phosphorus and $214.5 \mathrm{~kg} / \mathrm{ha}$ available potassium content. Data were recorded on mite, fungal spot and fruit cracking incidence. The data were analyzed statistically as per the methods suggested by Gomez and Gomez (1984). The mite (Tenuipalpus punicae) and fungal spot (Colletotrichum gloeosporiodes) incidence were observed from top, middle and lower portion of selected plants in all four directions 
(Haldhar \& Maheshwari 2018). The per cent incidence of mite and fungal spot was calculated as below.
Mite incidence $(\%)=$ $\mathrm{x} 100$

Total number of leaves observed Total number of infected leaves/fruits

Fungal spot incidence $(\%)=$ X 100

Total number of infected leaves

Figure 1. Mean monthly weather parameters recorded during experimentation
Results and Discussion
$\%)$ and fungal spot (23.67 and 19.02
$\%)$

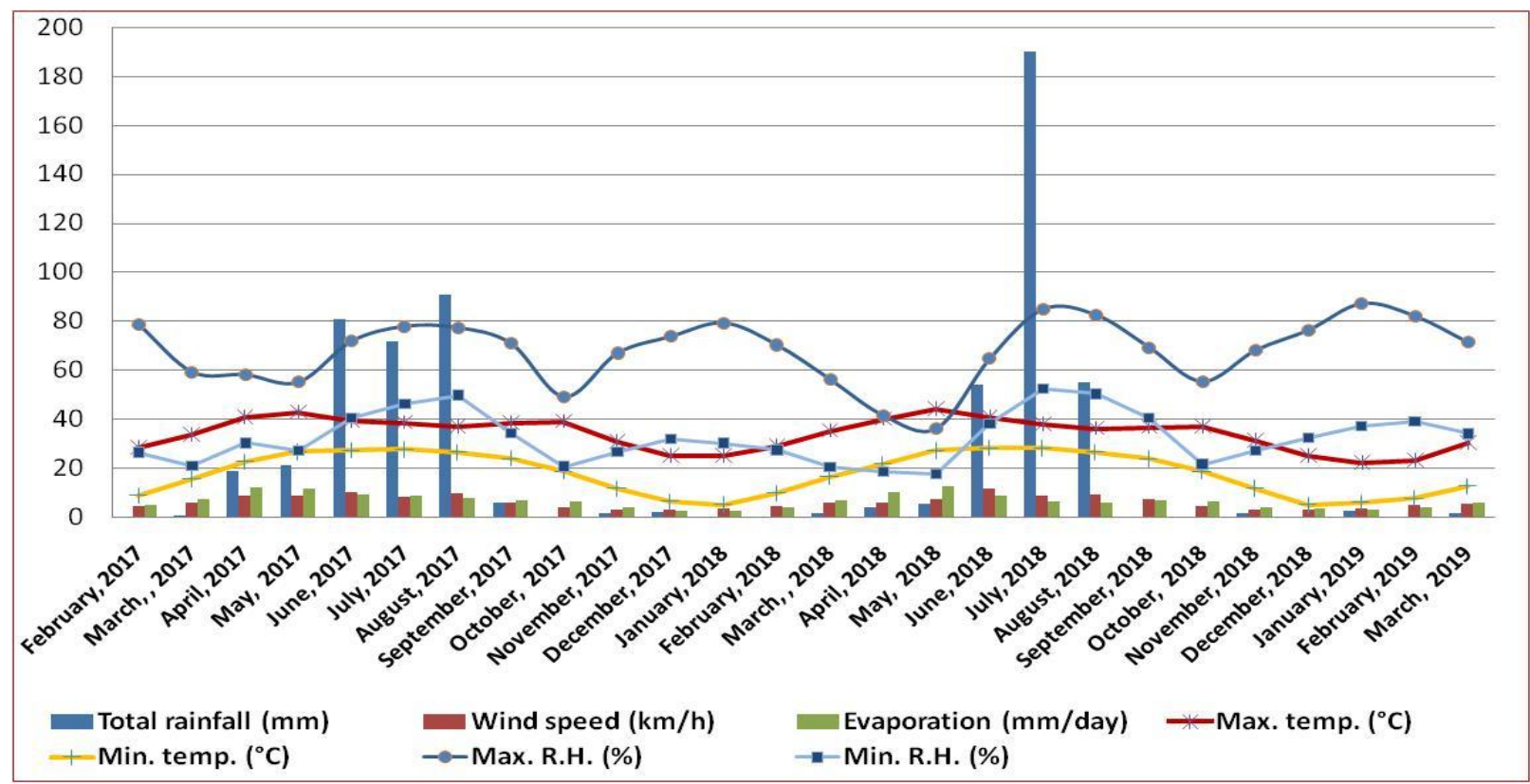

The data presented in Table 1 divulged that horticultural interventions significantly incidence recorded in control natural reduced mite, fungal spot incidence and fruit cracking in pomegranate. Among different horticultural interventions, significantly minimum mite (10.16 and $9.10 \%$ ) and fungal spot (12.90 and $12.54 \%$ ) incidence were recorded in withholding irrigation during June + pruning and thinning $\left(\mathrm{P}_{4}\right)$ treatment as compared to maximum mite (21.59 and 19.07 flowering $\left(\mathrm{P}_{0}\right)$ treatment in the years 2017-18 and 2018-19, respectively. Among horticultural interventions, significantly minimum fruit splitting (1.56 and 1.76 $\mathrm{kg} /$ plant) was recorded in withholding irrigation during June + pruning and thinning $\left(\mathrm{P}_{4}\right)$ treatment as compared to control $\left(\mathrm{P}_{0}\right)$ with fruit splitting (2.11 and $2.96 \mathrm{~kg} / \mathrm{plant})$ in the years 2017-18 and 2018-19, respectively. Table 1. Effect of horticultural interventions on mite, fungal spot and fruit cracking incidence of pomegranate

\begin{tabular}{|c|c|c|c|c|c|c|}
\hline \multirow[t]{2}{*}{ Treatments } & \multicolumn{2}{|c|}{ Mite incidence (\%) } & \multicolumn{2}{|c|}{$\begin{array}{c}\text { Fungal spot incidence } \\
(\%)\end{array}$} & \multicolumn{2}{|c|}{$\begin{array}{c}\text { Fruit cracking } \\
\text { (kg/plant) }\end{array}$} \\
\hline & 2017-18 & 2018-19 & 2017-18 & 2018-19 & 2017-18 & 2018-19 \\
\hline $\mathrm{P}_{0}$ & 21.59 & 19.07 & 23.67 & 19.02 & 2.11 & 2.96 \\
\hline $\mathrm{P}_{1}$ & 16.97 & 17.42 & 18.74 & 17.14 & 2.30 & 2.87 \\
\hline
\end{tabular}




\begin{tabular}{ccccccc}
\hline & & & & & & \\
$\mathrm{P}_{2}$ & 14.81 & 13.39 & 17.98 & 15.89 & 1.49 & 2.85 \\
$\mathrm{P}_{3}$ & 12.32 & 10.96 & 15.29 & 13.90 & 2.44 & 2.22 \\
$\mathrm{P}_{4}$ & 10.16 & 9.10 & 12.90 & 12.54 & 1.56 & 1.76 \\
\hline $\mathrm{SEm} \pm$ & 0.66 & 0.65 & 0.80 & 0.74 & 0.06 & 0.06 \\
$\mathrm{CD}(5 \%)$ & 1.90 & 1.87 & 2.29 & 2.11 & 0.18 & 0.18 \\
\hline
\end{tabular}

The data presented in Table 2 revealed that ethrel application significantly reduced mite, fungal spot incidence and fruit cracking in pomegranate. Among chemical treatments, minimum mite (7.73 and $7.27 \%$ ) and fungal spot (11.63 and $9.06 \%)$ incidence were recorded in ethrel $3 \mathrm{ml} / \mathrm{l}\left(\mathrm{C}_{3}\right)$ treatment as against maximum mite (25.17 and $22.23 \%$ ) and fungal spot (25.03 and $22.71 \%$ ) incidence were recorded in control without chemicals

Table 2. Effect of chemical applications on mite, fungal spot and fruit cracking incidence of pomegranate

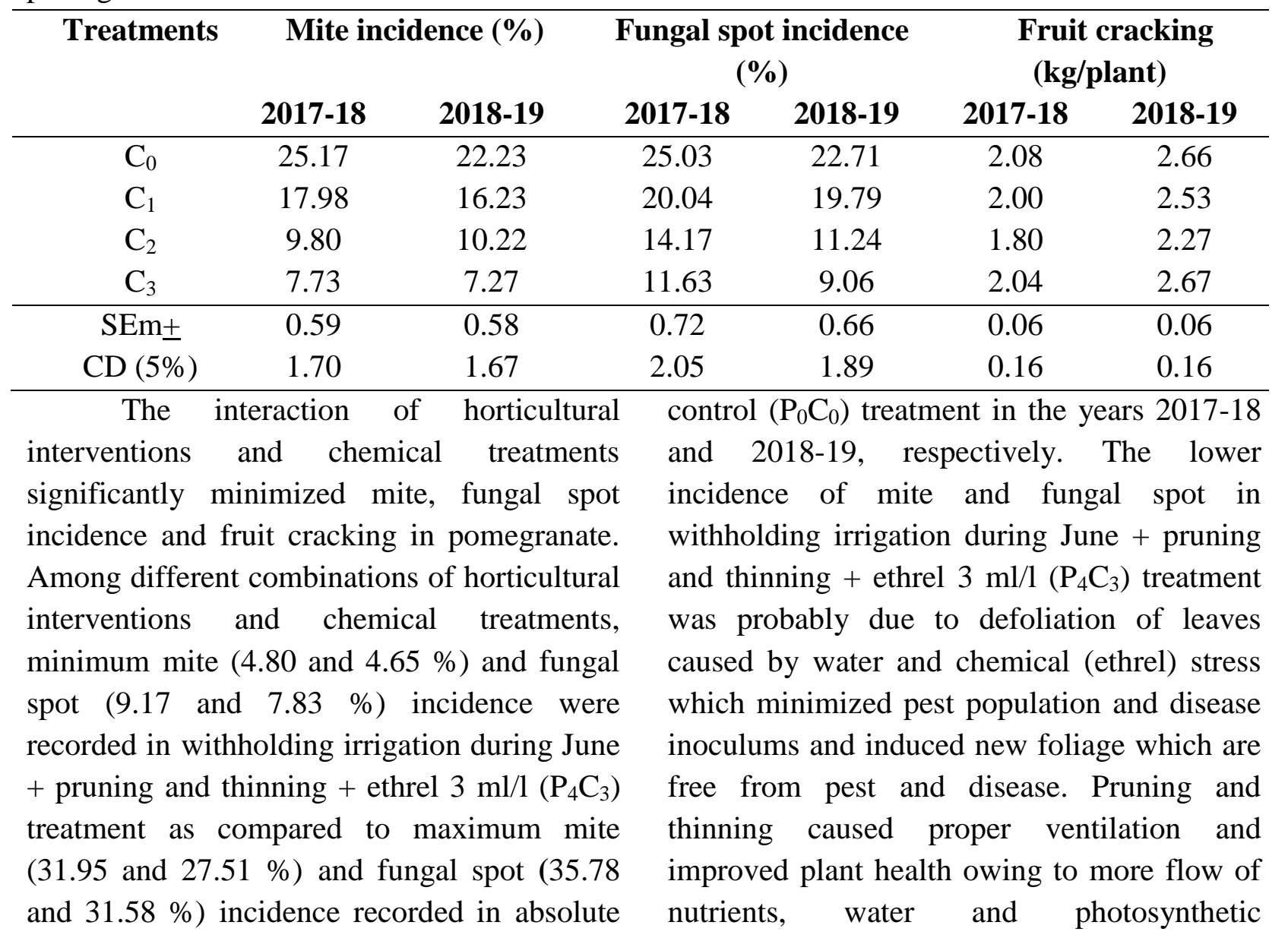


assimilates. Similarly, Pawar (1993) found that fruit spot and fruit borer infested fruit number was recorded minimum in higher pruning intensity. Chakma (2014) observed that disease incidence and severity significantly affected by different pruning intensity and lowest disease incidence and severity was recorded in higher pruning intensity. Sharma and Singh (2018) also noted that increasing pruning intensity with thinning significantly minimized disease severity on fruit and leaf surface of pomegranate.

Among interaction treatments, significantly lower fruit splitting (1.80 and $1.94 \mathrm{~kg} /$ plant) were recorded in withholding irrigation during June + pruning and thinning + ethrel $2 \mathrm{ml} / \mathrm{l}\left(\mathrm{P}_{4} \mathrm{C}_{2}\right)$ treatment as compared higher fruit splitting (2.51 and $3.24 \mathrm{~kg} /$ plant) were recorded in withholding irrigation during March without chemicals $\left(\mathrm{P}_{1} \mathrm{C}_{0}\right)$ treatment in the years 2017-18 and 2018-19, respectively
(Table 3). The low fruit splitting in withholding irrigation during June + pruning and thinning + ethrel $2 \mathrm{ml} / \mathrm{l}\left(\mathrm{P}_{4} \mathrm{C}_{2}\right)$ treatment might be attributed to induction of flowering and fruit development during favorable climatic condition, low variation in diurnal temperature, low incidence of mite and fungal spot under hot arid climate. Similarly, Lawande (2000) also reported that fruit cracking at maturity due to day-night temperature variation. Similar results were also reported by Pawar (1993), Chakma (2014) and Hiremath et al. (2018) who observed that fruits splitting significantly influenced by pruning intensity and minimum fruits cracking was recorded in higher pruning intensity as compared to maximum in unpruned plants. Korde (2015) also reported that the spraying of ethrel $(0.2 \%)$ reduced fruits splitting in pomegranate.

Table 3. Interaction effect of horticultural interventions and chemical applications on mite, fungal spot and fruit cracking incidence of pomegranate

\begin{tabular}{ccccccc}
\hline $\begin{array}{c}\text { Treatmen } \\
\text { ts }\end{array}$ & \multicolumn{2}{c}{ Mite incidence (\%) } & \multicolumn{2}{c}{$\begin{array}{c}\text { Fungal spot incidence } \\
(\%)\end{array}$} & \multicolumn{2}{c}{$\begin{array}{c}\text { Fruit cracking } \\
\text { (kg/plant) }\end{array}$} \\
& $\mathbf{2 0 1 7 - 1 8}$ & $\mathbf{2 0 1 8 - 1 9}$ & $\mathbf{2 0 1 7 - 1 8}$ & $\mathbf{2 0 1 8 - 1 9}$ & $\mathbf{2 0 1 7 - 1 8}$ & $\mathbf{2 0 1 8 - 1 9}$ \\
\hline $\mathrm{P}_{0} \mathrm{C}_{0}$ & 31.95 & 27.51 & 35.78 & 31.58 & 2.11 & 2.71 \\
$\mathrm{P}_{0} \mathrm{C}_{1}$ & 20.41 & 16.81 & 24.98 & 25.00 & 2.21 & 3.14 \\
$\mathrm{P}_{0} \mathrm{C}_{2}$ & 19.30 & 18.33 & 18.17 & 9.94 & 1.86 & 2.65 \\
$\mathrm{P}_{0} \mathrm{C}_{3}$ & 14.70 & 13.61 & 15.78 & 9.56 & 2.27 & 3.33 \\
$\mathrm{P}_{1} \mathrm{C}_{0}$ & 31.02 & 27.51 & 25.83 & 24.83 & 2.51 & 3.24 \\
$\mathrm{P}_{1} \mathrm{C}_{1}$ & 19.58 & 21.03 & 23.64 & 21.78 & 2.23 & 2.81 \\
$\mathrm{P}_{1} \mathrm{C}_{2}$ & 10.34 & 14.51 & 13.50 & 13.67 & 1.93 & 2.46 \\
$\mathrm{P}_{1} \mathrm{C}_{3}$ & 6.93 & 6.62 & 12.00 & 8.28 & 2.53 & 2.95 \\
$\mathrm{P}_{2} \mathrm{C}_{0}$ & 25.31 & 23.47 & 24.89 & 23.50 & 1.70 & 3.06 \\
$\mathrm{P}_{2} \mathrm{C}_{1}$ & 20.56 & 17.67 & 20.44 & 19.33 & 1.50 & 2.78 \\
$\mathrm{P}_{2} \mathrm{C}_{2}$ & 7.17 & 6.68 & 15.35 & 10.89 & 1.18 & 2.47 \\
$\mathrm{P}_{2} \mathrm{C}_{3}$ & 6.22 & 5.73 & 11.25 & 9.83 & 1.58 & 3.10
\end{tabular}




\begin{tabular}{ccccccc}
\hline $\mathrm{P}_{3} \mathrm{C}_{0}$ & 19.67 & 16.80 & 21.22 & 16.83 & 2.57 & 2.43 \\
$\mathrm{P}_{3} \mathrm{C}_{1}$ & 17.35 & 15.31 & 17.66 & 15.72 & 2.59 & 2.30 \\
$\mathrm{P}_{3} \mathrm{C}_{2}$ & 6.27 & 6.00 & 12.33 & 13.28 & 2.23 & 1.83 \\
$\mathrm{P}_{3} \mathrm{C}_{3}$ & 5.99 & 5.72 & 9.96 & 9.78 & 2.36 & 2.31 \\
$\mathrm{P}_{4} \mathrm{C}_{0}$ & 17.89 & 15.85 & 17.44 & 16.78 & 1.50 & 1.84 \\
$\mathrm{P}_{4} \mathrm{C}_{1}$ & 12.03 & 10.31 & 13.50 & 17.11 & 1.48 & 1.60 \\
$\mathrm{P}_{4} \mathrm{C}_{2}$ & 5.92 & 5.58 & 11.50 & 8.44 & 1.80 & 1.94 \\
$\mathrm{P}_{4} \mathrm{C}_{3}$ & 4.80 & 4.65 & 9.17 & 7.83 & 1.46 & 1.64 \\
\hline $\mathrm{SEm} \pm$ & 1.33 & 1.30 & 1.60 & 1.48 & 0.13 & 0.13 \\
$\mathrm{CD}(5 \%)$ & 3.80 & 3.74 & 4.59 & 4.22 & 0.36 & 0.37 \\
\hline
\end{tabular}

\section{Conclusion}

In pomegranate, most of the pest and disease infest foliar parts of plants particularly leaves. During flower regulation plants were subjected to water stress for one month with application of ethrel to force the plant to go into rest by defoliation. These water and chemical (ethrel) stresses caused defoliation in pomegranate (80-90\%) and plant became leafless. After that Bordeaux mixture $1 \%$ applied as a phytosanitary measure. Flower regulation also reduce pest and diseases particularly mite and fungal spot incidence in pomegranate through defoliation and enhanced management. It concluded that withholding irrigation during June + pruning + thinning with ethrel $2 \mathrm{ml} / \mathrm{l}$ treatment significantly reduced fruit cracking through induction of flowering and fruit growth during optimal climatic conditions and reduction of mite \& fungal spot incidence.

\section{References}

Anonymous. 2019. Area and production of horticulture crops for 2018-19 $\left(3^{\text {rd }}\right.$ Advance Estimate). Department of Agriculture, Cooperation \& Farmers' Welfare, Government of India, pp. 1.
Anonymous. 2020. Annual Report-2019, ICAR-Central Institute for Arid Horticulture, Bikaner, Rajasthan, India. pp.7.

Chakma J. 2014. Effect of different orchard management practices on the growth, productivity and rejuvenation of declining trees of pomegranate (Punica granatum L.) cv. Kandhari Kabuli. M.Sc. Thesis submitted to Dr. YSPUHF, Solan, India.

Gomez KA. \& Gomez AA. 1984. Statistical procedures for agricultural research. 2nd edn., John Wiley and Sons. Inc., New York.

Haldhar SM \& Maheshwari SK. 2018. Insectpests management in arid and semi-arid horticultural crops. Technical Bulletin, No: 64, ICAR-CIAH, Bikaner, pp 1-42.

Hiremath A, Patil SN, Hipparagi K, Gandolkar K \& Gollagi S. 2018. Influence of pruning intensity on growth and yield of pomegranate (Punica granatum L.) cv. Super Bhagwa under organic conditions. Journal of Pharmacognosy and Phytochemistry, 7(2), 1027-31. 
Korde SM. 2015. Studies on the effect of chemicals and growth regulators on regulation of flowering flush in pomegranate (Punica granatum L.). M.Sc. Thesis submitted to VNMAU, Parbhani-431 402 (MS) India.

Kumar R, Berwal MK \& Saroj PL. 2019a. Morphological, physiological, biochemical and molecular facet of drought stress in horticultural crops. International Journal of Bio-resource and Stress Management, 10(5), 545560.

Kumar R, Meena R, Sharma BD \& Saroj PL. 2018. Production technology of pomegranate in arid region. CIAH/Tech./Bull. No. 65, ICAR-Central Institute for Arid Horticulture, Bikaner, Rajasthan, India.

Kumar R, Saroj PL \& Sharma BD. 2019b. Flower regulation in pomegranate for higher yield, improved quality and enhanced management - a review. Fruits, The International Journal of Tropical and Subtropical Horticulture, 74(4), 150-166.

Kumar R, Saroj PL, Sharma BD \& Yadav PK. 2020. Studies on flowering induction, sex ratio and fruit set improvement in pomegranate. Indian Journal of Horticulture, 77(4), 610-618.

Lawande KE. 2000. Pomegranate production technology. Lecture delivered during training on "Changing scenario in Arid Horticulture" held during $20-29^{\text {th }}$ September 2000 at NRC for Arid Horticulture, Bikaner.

Maheshwari SK \& Haldhar SM. 2018. Disease management in arid horticultural crops. Technical Bulletin, No: 68, ICARCIAH, Bikaner, pp 1-42.

Pawar SK. 1993. Pruning studies in pomegranate (Punica granatum L.) cv. Ganesh. M.Sc. Thesis submitted to MPKV, Rahuri, MS, India, 1-131.

Saroj PL \& Kumar R. 2019. Recent advances in pomegranate production in India-a review. Annals of Horticulture, 12 (1), $1-10$.

Sharma DP \& Singh N 2018. Effect of rejuvenation pruning on the growth, productivity and disease incidence in declining trees of pomegranate (Punica granatum L.) cv. Kandhari Kabuli. Journal of Applied and Natural Science, 10(1), 358-362. 